\title{
The actuation of Physioterapy in the certifications of occupational quality, health and safety
}

\author{
Helenara Salvati Bertolossi Moreira ${ }^{a}$ Bruna Talini ${ }^{b}$ Isabele Maia Galvão ${ }^{c}$ José Mohamud Vilagra $^{d}$, Eduardo \\ Gallas Leivas ${ }^{e}$, Abel Santos de Oliveira Júnior ${ }^{f}$ \\ ${ }^{a}$ Universidade Estadual do Oeste do Paraná Departament of Pysicotherapy, Cascavel, Paraná, Brasil \\ ${ }^{\mathrm{b}}$ Phisicoterapy in Cascavel \\ ${ }^{\mathrm{c}}$ Student of Physical Therapy course from Universidade Estadual do Oeste do Paraná - UNIOESTE \\ ${ }^{d}$ Universidade Estadual do Oeste do Paraná Departament of Pysicotherapy \\ ${ }^{e}$ Phisicoterapy in Cascavel, Paraná - professor in Inspirar College \\ ${ }^{\mathrm{f}}$ English teacher and student nt letters in Universidade Estadual do Oeste do Paraná-UNIOESTE, Cascavel, \\ Paraná, Brasil
}

\begin{abstract}
To be distinguished from other companies, organizations are searching norms of certifications, such as ISO 9001, OHSAS 18001 and BS 8.800 to become more competitive in the work market, offering health and safety to the worker and quality to the customer. This extends the performance field of the Physiotherapist, who can use their knowledge to favor the processes of implementation of these certifications. The present work aims to identify the performance of the Physiotherapist in such processes of certification, as well as to verify their knowledge concerning the norms of certification and the performance in the occupational environment. Methodology: The population was constituted by the physiotherapists who had participated at the $4^{\circ}$ FISIOTRAB, the sample was composed by 30 physiotherapists, a questionnaire with pertinent questions to the study was applied. Results: $34 \%$ of the interviewed did not know what OHSAS 18001 and ISO 14001 were, 66\% did not know about the BS 8,800 certification. $76 \%$ of the interviewed had never participated in the implementation of certification norms; among those who had participated $28 \%$ were present during the implementation of ISO 9001 , $57 \%$ at the implementation of OHSAS 18001 and 15\% at that of both OHSAS and ISO 14001 together. Given that, from the $24 \%$ that had already acted in such implementations, $70 \%$ possess a specific formation in Occupational Physiotherapy. Conclusion: It was verified that the least part of physiotherapists have acted during the implementation of certification norms, and that even when they work in the Occupational Physiotherapy field many do not possess a deep knowledge on the different practical performances.
\end{abstract}

Keywords: Occupational Physiotherapy, Certification in Quality, Certification in Security and Health.

\section{Introduction}

In order to optimize productivity and quality in organizations it is necessary to implement a Management System which may provide health and security to the worker, thus assuring them ideal conditions for the performance of their activities, as a consequence, an increase in service and product quality happens, and it is optimized by means of Quality Management. There are numerous certifications focused on quality, health and security, they are mainly the following: the ISO (International Organization for Standardization), OHSAS 18001, (Occupational Health and Safety Assessment Series) and BS 8.800 (British Standards), these certifications aim to establish elements for the effective application of a Management System which provide Security, Health and Quality in companies, and as a consequence, to make the company more active in the work market.

During the implementation of certification norms, the possibility for actuation of Physiotherapy in an area of the work market in which there is little intervention of it is verified. Occupational Therapy, which is currently based on ergonomics, biomechanics and kinesiotherapy besides the basic knowledge of the physiotherapist, which, along with an interdisciplinary team, aims to increase the

*Corresponding author: E-mail: helenarasbm@,hotmail.com Rua Souza Naves 1605 , Cascavel, Paraná, Brasil 
worker's life quality, preventing them from Musculoskeletal Disorders, providing welfare, what optimizes the performance and productivity at work $[1,3]$.

Management of security and health at work is based on the worker, aiming to identify the risks they may be exposed to during labor activity, correlating to the pertinent legislation. Focused on this knowledge, norms of security and health are created and implemented [2,5]. The implementation of a Management of security and health at work allows that the company control and reach its performance, an objective that was imposed by the company itself. This kind of management will bring benefits such as: decrease in number and seriousness of accidents [9], maintenance of a good relationship with the company worker association, strengthening of the organization image, certainty of careful actuation, development of solutions for the prevention of accidents and occupational diseases, control over accident costs, better relationship between government and industry, and many others [3]. The OHSAS 18001 and BS 8.800 are two certification norms that aim to implement Occupational Health and Safety (OHS) Systems by establishing guidelines in order to provide occupational safety and health as well as to control the risks concerning all the involved personnel. [1]. OHSAS 18001 and BS 8.800 allow a standardization of the OHS systems, enabling modernization to companies, assuring continuous improvement, making the company more competitive and providing health and safety to the worker.

Such certifications in quality, safety and health set a new market area for the intervention of the Occupational Physiotherapist, who applies all their knowledge and tools in order to favor the implementations and thus, along with their multiprofessional team, to provide ideal conditions in the occupational scope.

\section{Materials and methods}

The research is characterized as transversal and exploratory with a quantitative approach. The population was constituted by a group of physiotherapists who took part in a Brazilian Occupational Physiotherapy Congress.

The sample was composed by 30 physiotherapists, which were requested to answer a questionnaire about their actuation in the processes of certification in occupational quality, health and safety.

The gathered data was statistically analyzed in Microsoft Office Excel 2007 software and set in graphs and tables to facilitate the comparison between them, later, a descriptive analysis focusing on the work objectives took place.

\section{Results}

The questionnaire was applied to 30 physiotherapists, of which $55 \%$ were specifically post-graduated in occupational physiotherapy, while $45 \%$ were only graduated in Physiotherapy.

Among the subjects, $34 \%$ did not know what OHSAS 18001 and ISO 14001 were. Concerning to BS 8.800 the number was even higher: $66 \%$. ISO 9001 was the most known certification; only one subject could not answer about it.

When asked whether they had ever took part in the implementation of a OHS certification, $76 \%$ answered that had never participated; $28 \%$ were present during the implementation of ISO 9001; 57\% of OHSAS 18001 and $15 \%$ of both OHSAS and ISO 14001 together.

When questioned about the different interventions that the Occupational Physiotherapist may act on, it was verified that the main answers were: Rehabilitation (62\%), Labor Gymnastics (69\%), ergonomics intervention (79\%) and admission exams $(20 \%)$.

Other answers which were given but not in a significant number were lectures, posture orientations, participation in surveys and consultations. None of the subjects answered that the physiotherapist is able to act in the implementation of certification processes.

\section{Discussion}

According to the Code of Ethics of the Physiotherapist, it is their main responsibility to improve their technical knowledge in order to benefit the client and profession [10], The Federal Council of Physiotherapy and Occupational Therapy (Coffito) affirms that permanent education is important for the professional [12]. With the continuous formation the professional becomes updated, searching for new information and specialties, thus having a broader ground which may allow them to ably act in their profession [14]. In the 
present study, it was verified that $71 \%$ of the physiotherapists who had acted in the implementation of certifications had taken a postgraduation course, what reflects that professionals who engage in continuous and specific formation participate in more complex processes.

The one thousand biggest companies in Brazil were questioned about their OHS systems, it was observed that $82.2 \%$ of them had ISO 9001, and 9.1\% OHSAS 18001 [16]. These results differ from those obtained in the present research, in which $57 \%$ of the subjects took part in the implementation of OHSAS 18001 and $29 \%$ of ISO 9001. The OHSAS aims to assure safety and health, such specification makes the actuation of the physiotherapist clearer than ISO 9001, which has as an objective quality, what justifies the data obtained in this research.

The physiotherapist has different actuations in the occupational environment, according to Baú [2], the occupational physiotherapist may act: in the prevention of musculoskeletal complaints; in occupational ergonomics studies; ergonomically intervening in awareness, correction or conception in the company; educating by means of capacitation, preventive training and awareness lectures; guiding the worker concerning to ergonomic and postural aspects during the accomplishment of occupational activities, as well as in activities out of the work place; observing the biomechanics in occupational activities and postural assessment; teaching postural reeducation techniques to prevent occupational injuries; implementing labor exercises and researching about occupational health, thus allowing divulgation of knowledge to other professionals of the area.

According to Kaizer [14], the evolution of competitive market led companies to become more worried with the health and safety of the worker in order to optimize their productivity. With this point of view, new areas of practical actuation emerge, such as the actuation in the Occupational Health Medical Control Program (PCMSO), more specifically in admission, dismissal and periodic exams.

In the present research it was possible to observe that $34 \%$ of the subjects named the possible ergonomics actuation as a practical area for the physiotherapist. One of the most common interventions is the Occupational Ergonomics Analysis (AET), which is a tool that may be used to assess the conditions of the workplace as well as of the workers [13], playing an important role in the implementation of certification norms.
The AET has an objective to conduct and orientate the necessary adaptations to improve the relationship between men and their work [14], so that during the implementation of certifications the occupational conditions are adequate, favoring the implementation in health and safety management as well as in quality.

\section{Conclusion}

The physiotherapist has the necessary conditions and tools to work in the implementation of certification processes, however that area is not really explored. In the present study it was possible to verify that the least part of the physiotherapists act during the implementation of the certification norms, and that even among those who work in the area of Occupational Physiotherapy many do not have deep knowledge on the different practical actuations. One was able to observe the need for professional improvement so that the physiotherapists have the necessary knowledge to intermediate in the different approaches of the Occupational Physiotherapy. In that sense, a prepared and alert professional will be able to act in this area along with other professionals of the occupational environment, as well as to provide health, safety and quality at work.

\section{References}

[1]BaúL.MErgonomia, legislação, reabilitação. Curitiba: Clãdosilva, 2002.

[2]-Benite AG. Sistema de gestão da segurança e saúde no trabalho: conceitos e diretrizes para a implementação da norma OHSAS 18001 e guia ILO OSH da OIT. São Paulo: O nome da rosa, 2004.

[3]-Cicco FD. OHSAS 18001: especificações para Sistemas de Gestão da Segurança e Saúde no Trabalho. São Paulo: Risk Tecnologia, 1999.

[4]-Paladini EP. Gestão da qualidade: teoria e prática. 2 ed. São Paulo: Atlas,2004.

[5]-Oliveira et al. Gestão da qualidade: tópicos avançados. São Paulo: Thomson,2004.

[6]-Maciel JLDL. Proposta de um modelo de integração da gestão da segurança e da saúde ocupacional à gestão da qualidade total [dissertação online]. Florianópolis: Engenharia de Produção, Universidade Federal de Santa Catarina; 2001. [Acesso em: 20 maio 2008]. Disponível em: http://teses.eps.ufsc.br/defesa/pdf/3925.pdf.

[7]-Stachelski L. O impacto da implantação da estratégia de gestão da Qualidade total na cultura organizacional: um estudo de caso [dissertação online]. Florianópolis: Engenharia de Produção, Universidade Federal de Santa Catarina; 2003. [Acesso em: 20 maio 2008]. Disponível em: http://teses.eps.ufsc.br 


\section{$/$ defesa/pdf/4507.pdf.}

[8]12-International Organization for Standardization. Discover ISO [texto on line]. Disponível em: http://www.iso.org/iso/about/discover-iso_isos-name.htm

[9]-Mello CHP et al. ISO 9001:2000: Sistema de gestão da qualidade para operações de produção e serviços. São Paulo: Atlas, 2002

[10]14-Lebuisson DA, Arson B, Abenhaïm A, Albou-Ganem C, Assouline M, Chong SD, Danan A, Montefiore G, Montin JF, Nguyen-Khoa JL, Pietrini D, Saragoussi JJ, Trong T, Amar R. Certification ISO 9001:2000 des traitements réfractifs par laser córneen._Journal Français D'Ophtalmologie. [periódico on line] 2005; 28(5): 562-570.[citado em: 16 jun. 2008]. Disponível em: http://www.em-consulte.com//article/113022

[11]15- Conselho Federal de Fisioterapia e Terapia Ocupacional. Código de ética profissional de fisioterapia e terapia ocupacional aprovado pela resolução coffito-1

e 3 de julho de 1978 [texto online]. Disponível em:http://www.coffito.org.br/conteúdo /con_view.asp?secao=26

[12]16- Conselho Federal de Fisioterapia e Terapia Ocupacional. Formação profissional [texto online]. Disponível em: http://www.coffito.org.br/conteudo/con view.asp? secao $=30$

[13]- Gasque KCGD, Costa SMS. Comportamento dos professores da educação básica na busca da informação para formação continuada. Ciência da Informação [periódico online] 2003; 32(3). [Acesso em: 16 set. 2008]. Disponível em: http://www.scielo.br/scielo.php?script=sci arttext\&pid=S0100$19652003000300007 \& 1 \mathrm{ng}=\mathrm{pt} \& \mathrm{nrm}=$ iso.

[14]-Feitosa BDC, Moreira REDA. Análise ergonômica do trabalho - um estudo de caso em uma pequena empresa de perfumaria e cosméticos. [Acesso em 4 out. 2007] Disponível em: http://www.artigocientifico.com.br/uploads/artc_1172131371 27.pd 